\title{
Effects of an actual insulin injection demonstration on insulin acceptance among patients with T2DM: a pragmatic randomized controlled trial
}

\author{
ATTHAYAPORN CHOOMAI ${ }^{1}$, APICHAI WATTANAPISIT $^{2,3^{*}}$, ORATHAI TIANGTAM $^{1,4}$ \\ ${ }^{1}$ Thasala Hospital, Thasala, Nakhon Si Thammarat, Thailand \\ ${ }^{2}$ School of Medicine, Walailak University, Thasala, Nakhon Si Thammarat, Thailand \\ ${ }^{3}$ Walailak University Hospital, Thasala, Nakhon Si Thammarat, Thailand \\ ${ }^{4}$ Thonburi Thung Song Hospital, Thung Song, Nakhon Si Thammarat, Thailand
}

\begin{abstract}
Introduction. Insulin injection refusal is a challenge when initiating insulin therapy. This study aimed to investigate the effects of an actual insulin injection demonstration on insulin acceptance in patients with type 2 diabetes mellitus (T2DM).

Methods. A pragmatic randomised controlled trial (RCT) was conducted. The participants were patients with T2DM aged 18-65 years old. The control group (CG) received an educational programme regarding T2DM. The intervention group (IG) received the educational programme and actual insulin injection demonstration (a physician-led sample insulin injection using an insulin pen). The main outcome was immediate insulin acceptance. Insulin adherence, glycated haemoglobin (HbAlc), and adverse effects of insulin were evaluated at three months after the intervention.

Results. Forty-nine participants with T2DM were allocated to the IG $(n=24)$ and the CG $(\mathrm{n}=25)$. The immediate insulin acceptance was significantly higher in the IG $(79.17 \%, \mathrm{n}=19)$ than the CG $(24.00 \%, n=6 ; p<0.05$; RR 3.30, 95\% CI 1.59 to 6.82$)$. At the three-month follow-up, the insulin adherence was significantly different between the two groups (IG: $75.00 \%, \mathrm{n}=18$ vs CG: $20.00 \%, \mathrm{n}=5 ; \mathrm{p}<0.05$; RR 3.75, 95\% CI 1.66 to 8.49). Adverse effects of insulin, HbA1c levels, and changes in $\mathrm{HbA} 1 \mathrm{c}$ levels between the IG and CG were not different.

Conclusion. The physician-led actual insulin injection demonstration is effective for increasing insulin acceptance among participants with T2DM.
\end{abstract}

Key words: injection demonstration, insulin, insulin acceptance, treatment, type 2 diabetes mellitus.

\section{What is new? What is important?}

This pragmatic randomised controlled trial showed a higher insulin acceptance rate in the intervention group (education and actual insulin injection demonstration) compared with the control group (education; $79.17 \%$ vs $24.00 \%, \mathrm{p}<0.05$ ). The actual insulin injection demonstration can be adapted for ambulatory care settings.

\section{INTRODUCTION}

The major pathogenesis of Type 2 diabetes mellitus (T2DM) is insulin resistance [1,2]. Patients of $\mathrm{T} 2 \mathrm{DM}$ are at increased risk of micro and macrovascular complications and decreased quality of life [3-7]. T2DM is considered a global health challenge and has been addressed as part of the United Nations Sustainable Development Goal on health and well-being ( $3^{\text {rd }}$ goal) [8]. In 2017, T2DM accounted for more than 462 million cases worldwide, and the prevalence increased by $30.5 \%$ within ten years [9]. The International Diabetes Federation reported 463 million cases of DM among population aged 20-79 years in 2019 and estimated the global prevalence would reach 700 million cases by 2045 [10]. Moreover, it causes more than a million deaths per year [11]. Overall, T2DM contributes to morbidity and premature mortality and to a global economic burden $[12,13]$.

Glycaemic or glucose control is the main target for management of patients with T2DM. Lifestyle modification, including diet control and physical activity, is basic treatment for patients with T2DM [14]. Additionally, cardiovascular risk reduction programmes, such as smoking cessation, blood pressure control, lipid management, and antiplatelet therapy, are essential to prevent and delay microvascular complications [15]. Several classes of oral medications are used to treat T2DM 
$[16,17]$. Insulin therapy, an injectable agent, is recommended for patients with T2DM who fail to achieve the glycaemic goal using adequate oral medications [18].

Insulin injection refusal or psychological insulin resistance is a challenge when initiating insulin therapy. The prevalence of insulin injection refusal is diverse in different settings, ranging from 33\% to $74 \%$ of patients [19-23]. A systematic review of 25 research articles indicated the barriers to insulin injection initiation, including patient-related factors, healthcare professional factors, and system factors [24]. The aforementioned review emphasised fear of needles, injection, and pain as a major concern among patients with T2DM [24]. The authors hypothesised that an actual insulin injection demonstration, which illustrated the use of an insulin pen and a real feeling of injection, could help the patients accept insulin therapy. This study aimed to investigate the effects of an actual insulin injection demonstration on insulin acceptance in patients with T2DM.

\section{MATERIALS AND METHODS}

\section{Study design}

A pragmatic randomised controlled trial (RCT) was conducted between October 2018 and March 2020 at a hospital-based non-communicable disease clinic in Thailand. The clinic was led by physicians in three different medical specialties, including general practitioners (i.e., physicians who were not certified in any medical specialty), family physicians (i.e., physicians who were certified in a family medicine specialty), and internists (i.e., physicians who were certified in an internal medicine specialty). The triage system was based on the patients' home addresses and conditions. For example, a patient, who came from a sub-district and had an incharge family physician would see their family physician. Others, who were classified by their clinical conditions as non-medically complex would be seen by general practitioners. Patients with medically complex conditions such as poorly controlled conditions and end organ damage would be seen by internists.

Patients with T2DM aged 18-65 years old were invited. The inclusion criteria included: (i) glycated haemoglobin $(\mathrm{HbA} 1 \mathrm{c}) \geq 7.0 \%$ lasting more than one year; (ii) receiving maximum doses of three oral medications (glipizide $20 \mathrm{mg} /$ day, metformin
2,000-3,000 mg/day, and pioglitazone $15-45 \mathrm{mg} /$ day); and (iii) having a history of insulin therapy refusal.

The exclusion criteria were patients who had one of the following conditions: (i) chronic kidney disease stage 4 or 5; (ii) liver cirrhosis graded ChildPugh class B or C; (iii) no potential to manage insulin therapy (e.g., physical limitations, no support from families or caregivers); and (iv) a history of poor medication compliance.

\section{Sample size and randomisation}

The sample size was calculated using a sample size calculation programme; i.e., n4Studies [25]. A function for an RCT for binary data was selected. The data were entered as the following. The prevalence of insulin acceptance varied among studies [26]. Therefore, the prevalence of $50 \%$ $\left(p_{\text {control }}=0.5\right)$ was estimated for the conventional intervention, and $90 \%\left(p_{\text {intervention }}=0.9\right)$ was estimated for the new intervention (estimated by the observation of previous practices in the study site among inpatients). The values of 0.05 for type I $(\alpha=0.05)$ error and 0.2 for type II $(\beta=0.2)$ errors were assigned [27]. This presented a power of 0.8 . A 1:1 ratio was performed to allocate the intervention group (IG) and the control group (CG). Based on the values assigned, the calculated sample size was 20 for each group. In addition, the sample size calculation used a continuity factor that indicated 25 for each group. Therefore, 20-25 participants in each group were recruited.

Patients were invited to participate in the study on the date of clinic visits. Each patient was assessed for eligibility and asked to choose a sealed envelope, which contained the IG or CG assignment. The enrollment and allocation processes were conducted prior to the physician consultation. One physician (internist: AC or OT) administered the interventions. Both participants and physicians were not blinded.

\section{Data collection and outcome measurement}

At baseline, participants in both groups were requested to complete a questionnaire consisting of questions on personal characteristics (i.e., sex, age, occupation, tobacco use, complications (micro and macrovascular complications, and diabetic neuropathy), duration of T2DM from diagnosis, underlying illnesses, and history of insulin refusal). Body weight and body mass index (BMI) data were collected. Oral diabetes medications, including medication names and dose per day, were recorded 
from the electronic medical records. Blood tests included fasting plasma glucose (FPG), HbAlc, serum creatinine, and the estimated glomerular filtration rate (eGFR). The main outcome of the study was immediate insulin acceptance. The authors considered acceptance or not at the time of prescribing medications. At the three-month follow-up, the physicians appointed a single visit and asked participants about current insulin use (insulin adherence) and adverse effects of insulin. A blood test for $\mathrm{HbAlc}$ was performed. The normal diabetes care processes continued after the interventions and the follow-up visit.

\section{Interventions}

The physicians educated participants in both groups using printout graphic materials regarding basic knowledge of T2DM, treatments (lifestyle modification, oral medications, and insulin therapy), target goals, and complications (micro and macrovascular complications and diabetic neuropathy). For the IG, the physician presented a reusable insulin pen and introduced the components of the insulin pen. Subsequently, the physician explained the injection techniques, including preparation of injection sites and rotation of injection sites. The physician performed an actual insulin injection demonstration using an empty insulin pen with a 31 gauge $\times 5 \mathrm{~mm}$ needle to penetrate the subcutaneous fat in the participant's abdomen.

Participants in both groups were asked whether they agreed to start insulin therapy. The physicians prescribed a premixed insulin regimen (biphasic isophane insulin 30/70) at 14-16 IU before breakfast or dinner to replace a single dose of glipizide $(5-10 \mathrm{mg})$.

\section{Statistical analysis}

Descriptive data are presented as frequency, percentage, mean, and standard deviation (SD). The distribution of each continuous variable was tested using the Shapiro-Wilk test. Analytic statistics were applied to compare the outcomes between the IG and CG. An independent t-test or Mann-Whitney test was performed to analyse continuous variables. A chi-squared or Fisher's exact test was executed for categorical variables. An intention-to-treat analysis was employed. A p-value $<0.05$ was considered statistically significant. The data were managed and analysed with Microsoft Excel (Office 365 University package, Microsoft Inc., Redmond, WA, USA) and
Genstat $20^{\text {th }}$ Edition (VSN International, Hemel Hempstead, Hertfordshire, UK).

\section{Ethical approval}

The study protocol was approved by the Human Research Ethics Committee of Walailak University (protocol number: WUEC-18-111-01). Participation in the study was entirely voluntary. Written informed consent was obtained prior to participation in the study.

\section{RESULTS}

\section{Recruitment and follow-up}

The study enrollment began in October 2018 and follow-up of the last participant was completed in March 2020. Fifty-six participants with T2DM were enrolled and eligibility was assessed. Seven patients were excluded (i.e., ineligible patients were older than 65 years old). A total of 49 participants with T2DM were allocated to the IG $(n=24)$ and the CG $(n=25)$. The follow-up rate was $100 \%$.

\section{Baseline characteristics}

Most baseline characteristics of the participants did not vary. The majority of participants were females ( $\mathrm{IG}=54.17 \%$; $\mathrm{CG}=72.00 \%)$. The mean age was $53.92 \pm 7.29$ years in the IG and $53.00 \pm 8.62$ years in the CG. Table 1 shows the baseline characteristics of the participants in each group.

Table 2 presents outcome comparisons between the IG and CG. The immediate insulin acceptance rate was significantly higher in the IG $(79.17 \%$, $\mathrm{n}=19)$ compared to the CG $(24.00 \%, \mathrm{n}=6$; $\mathrm{p}<0.05$; RR 3.30, 95\%CI 1.59 to 6.82 ). The number needed to treat (NNT) with the actual insulin injection demonstration to accept insulin therapy was 1.81 .

\section{Study outcomes}

At three months, insulin adherence was significantly different between the two groups (IG: $75.00 \%, \mathrm{n}=18$ vs CG: $20.00 \%, \mathrm{n}=5 ; \mathrm{p}<0.05$; RR $3.75,95 \%$ CI 1.66 to 8.49 ). The NNT with the actual insulin injection demonstration to continue insulin therapy was 1.82 . The adverse effects of insulin use, HbA1c levels, and changes in HbA1c levels between the IG and CG were not significantly different. 
Table 1

Baseline characteristics

\begin{tabular}{|c|c|c|c|}
\hline Characteristic & $\begin{array}{l}\text { Intervention group } \\
\quad(n=24)\end{array}$ & $\begin{array}{l}\text { Control group } \\
\quad(n=25)\end{array}$ & p-value \\
\hline Sex & & & 0.20 \\
\hline Female (n (\%)) & $13(54.17)$ & $18(72.00)$ & \\
\hline Male (n (\%)) & $11(45.83)$ & $7(28.00)$ & \\
\hline Age [year] $($ mean \pm SD) & $53.92 \pm 7.29$ & $53.00 \pm 8.62$ & 0.69 \\
\hline Occupation & & & 0.38 \\
\hline Employed (n (\%)) & $19(79.17)$ & $17(68.00)$ & \\
\hline Unemployed (n (\%)) & $5(20.83)$ & $8(32.00)$ & \\
\hline Current smoking (n (\%)) & $4(16.00)$ & 0 & $0.11^{\dagger}$ \\
\hline Body weight $[\mathrm{kg}]($ mean $\pm \mathrm{SD})$ & $71.54 \pm 20.42$ & $67.52 \pm 12.14$ & 0.40 \\
\hline $\mathrm{BMI}\left[\mathrm{kg} / \mathrm{m}^{2}\right]($ mean $\pm \mathrm{SD})$ & $27.93 \pm 6.88$ & $27.34 \pm 4.49$ & $0.92^{\dagger \dagger}$ \\
\hline Complications (n (\%)) & $14(58.33)$ & $12(16.15)$ & 0.47 \\
\hline Insulin therapy refusal [number of attempts] (mean $\pm \mathrm{SD})$ & $1.67 \pm 1.09$ & $1.76 \pm 0.92$ & $0.52^{\dagger \dagger}$ \\
\hline \multicolumn{4}{|l|}{ Reasons of previous insulin refusal (n (\%)) } \\
\hline Fear of hypoglycaemia & 0 & 0 & $>0.99^{\dagger}$ \\
\hline Fear of kidney/liver failures & 0 & 0 & $>0.99^{\dagger}$ \\
\hline Fear of life-long insulin injections & $1(4.17)$ & 0 & $0.49^{\dagger}$ \\
\hline Fear of needles & $15(62.50)$ & $22(88.00)$ & $0.05^{\dagger}$ \\
\hline Feeling ashamed & $1(4.17)$ & 0 & $0.49^{\dagger}$ \\
\hline Inconvenience & $8(33.33)$ & $3(12.00)$ & $0.10^{\dagger}$ \\
\hline Lack of confidence in insulin self-injection & $2(8.33)$ & $8(32.00)$ & $0.07^{\dagger}$ \\
\hline Lack of knowledge of insulin therapy & $2(8.33)$ & $1(4.00)$ & $0.61^{\dagger}$ \\
\hline Perception of normal health conditions & $7(29.17)$ & $7(28.00)$ & 0.93 \\
\hline Symbol of severe diabetes mellitus & $1(4.17)$ & 0 & $0.49^{\dagger}$ \\
\hline Past history of DM [year] (mean $\pm \mathrm{SD}$ ) & $8.12 \pm 4.63$ & $8.56 \pm 6.12$ & 0.78 \\
\hline \multicolumn{4}{|l|}{ Underlying illnesses (n (\%)) } \\
\hline Cerebrovascular disease & 0 & 0 & $>0.99^{\dagger}$ \\
\hline Coronary artery disease & $1(4.17)$ & $1(4.00)$ & $>0.99^{\dagger}$ \\
\hline Dyslipidaemia & $5(20.83)$ & $6(24.00)$ & 0.79 \\
\hline Hypertension & $4(16.67)$ & $5(20.00)$ & $>0.99^{\dagger}$ \\
\hline \multicolumn{4}{|l|}{ Oral diabetes medications $[\mathrm{mg} /$ day $]($ mean $\pm \mathrm{SD})$} \\
\hline Glipizide & $20.00 \pm 0.00$ & $19.80 \pm 1.00$ & $>0.99^{\dagger \dagger}$ \\
\hline Metformin & $2120.83 \pm 276.20$ & $2126.00 \pm 298.65$ & $0.84^{\dagger \dagger}$ \\
\hline Pioglitazone & $26.88 \pm 10.82$ & $28.80 \pm 4.15$ & $0.70^{\dagger \dagger}$ \\
\hline Additional medication used (n (\%)) & 0 & 2 & $0.49^{\dagger}$ \\
\hline \multicolumn{4}{|l|}{ Blood tests $($ mean $\pm \mathrm{SD})$} \\
\hline $\mathrm{FPG}[\mathrm{mg} / \mathrm{dL}]$ & $209.92 \pm 52.62$ & $194.64 \pm 52.05$ & 0.31 \\
\hline $\mathrm{HbAlc}[\%]$ & $10.54 \pm 1.89$ & $10.41 \pm 1.58$ & 0.79 \\
\hline $\mathrm{Cr}[\mathrm{mg} / \mathrm{dL}]$ & $0.81 \pm 0.20$ & $0.68 \pm 0.19$ & $0.02 *$ \\
\hline $\mathrm{eGFR}\left[\mathrm{ml} / \mathrm{min} / 1.73 \mathrm{~m}^{2}\right]$ & $92.78 \pm 17.12$ & $100.56 \pm 17.21$ & $0.09^{\dagger \dagger}$ \\
\hline \multicolumn{4}{|c|}{$\begin{array}{l}\text { BMI = body mass index, } \mathrm{Cr}=\text { serum creatinine, } \mathrm{DM}=\text { diabetes mellitus, eGFR = estimated glomerular filtration rate, } \\
\mathrm{FPG}=\text { fasting plasma glucose, } \mathrm{HbA} 1 \mathrm{c}=\text { glycated haemoglobin, } \mathrm{SD}=\text { standard deviation. } \\
\text { 'Fisher's exact test } \\
{ }^{\dagger} \text { Mann-Whitney test } \\
\text { *Statistical significance }\end{array}$} \\
\hline
\end{tabular}


Table 2

Outcome comparisons between the intervention and control groups

\begin{tabular}{|c|c|c|c|c|}
\hline Outcome & $\begin{array}{l}\text { Intervention group } \\
\qquad(\mathrm{n}=\mathbf{2 4})\end{array}$ & $\begin{array}{l}\text { Control group } \\
\quad(n=25)\end{array}$ & p-value & $\begin{array}{c}\text { RR } \\
(95 \% \mathrm{CI})\end{array}$ \\
\hline $\begin{array}{l}\text { Immediate assessment } \\
\text { Insulin acceptance (n (\%)) } \\
\text { Yes } \\
\text { No }\end{array}$ & $\begin{array}{l}19(79.17) \\
5(20.83)\end{array}$ & $\begin{array}{c}6(24.00) \\
19(76.00)\end{array}$ & $0.0001 *$ & $\begin{array}{c}3.30 \\
(1.59 \text { to } 6.82)\end{array}$ \\
\hline $\begin{array}{l}\text { At } 3 \text { months after the intervention } \\
\text { Insulin adherence }(\mathrm{n}(\%)) \\
\text { Yes } \\
\text { No }\end{array}$ & $\begin{array}{c}18(75.00) \\
6(25.00)\end{array}$ & $\begin{array}{c}5(20.00) \\
20(80.00)\end{array}$ & $0.0001 *$ & $\begin{array}{c}3.75 \\
\text { (1.66 to } 8.49)\end{array}$ \\
\hline $\begin{array}{l}\text { Adverse effects of insulin (n (\%)) } \\
\text { Yes } \\
\text { No }\end{array}$ & $\begin{array}{c}3(12.50) \\
21(87.50)\end{array}$ & $\begin{array}{c}2(8.00) \\
23(92.00)\end{array}$ & $0.67^{\dagger}$ & $\begin{array}{c}1.56 \\
(0.28 \text { to } 8.55)\end{array}$ \\
\hline $\mathrm{HbA1c}[\%]($ mean $\pm \mathrm{SD})$ & $9.38 \pm 1.90^{\#}$ & $8.84 \pm 1.51$ & 0.28 & $\begin{array}{c}\text { Mean difference }(\mathbf{9 5 \%} \mathbf{C I}) \\
0.53 \\
(-0.45 \text { to } 1.51)\end{array}$ \\
\hline Change in $\mathrm{HbA} 1 \mathrm{c}[\%]($ mean $\pm \mathrm{SD})$ & $-1.63 \pm 2.65$ & $-1.57 \pm 1.71$ & $0.62^{\dagger \dagger}$ & $\begin{array}{c}-0.06 \\
(-1.35 \text { to } 1.23)\end{array}$ \\
\hline
\end{tabular}

HbA1c $=$ glycated haemoglobin, $\mathrm{RR}=$ relative risk, $\mathrm{SD}=$ standard deviation, $95 \% \mathrm{CI}=95 \%$ confidence interval.

${ }^{\dagger}$ Fisher's exact test

"Mann-Whitney test

*Statistical significance

\#One record was missed (used the baseline value).

At baseline, the fear of needles was a main reason for previous insulin refusal. Within the IG, 11 participants of $15(73.33 \%)$ who stated they had a fear of needles accepted insulin therapy after the actual insulin injection demonstration. On the other hand, six of $22(27.27 \%)$ participants who were afraid of needles in the $\mathrm{CG}$ accepted insulin injection.

\section{DISCUSSION}

Diverse barriers to insulin therapy were addressed in the literature previously [24, 28-30]. Fear of needles, pain, and inconvenience were found to be major reasons for previous insulin refusal among the participants in this study. Overcoming the barriers, supporting patient education and information, and countering the fear of needles or injection were key facilitators to initiate insulin [24]. A total of $27.27 \%$ of the participants who stated they had a fear of needles in the CG accepted insulin therapy after the educational programme. In addition, the actual insulin injection demonstration possibly increased the insulin acceptance rate up to $73.33 \%$ among participants who were afraid of needles and injections. Previous studies supported the potential for demonstrations of insulin injections to administer insulin therapy $[31,32]$. The different insulin acceptance rates between the IG and CG reflected that the actual insulin injection demonstration could be an additional intervention for insulin initiation. The actual insulin injection demonstration can help patients see the process and perceive the sensation of insulin injections. In addition, participants in the IG were more likely to continue insulin use.

The mean HbAlc levels at three months decreased in both groups, but were not statistically different between the two groups. There are two explanations for the findings. First, the initial insulin therapy in this study was prescribed as a substitute for a single dose of glipizide (5-10 mg). A single follow-up visit at 3 months was arranged as a routine visit. The authors could not make several appointments to monitor and adjust the dose of insulin due to the heavy workload of the clinic. The initial dose aimed to avoid hypoglycaemia and did not aim to provide a normal level of $\mathrm{HbAlc}$ [33]. However, the adjustment of insulin dose would continue as a routine diabetes care after the study to lower HbA1c steadily. Second, participants in both groups received one (i.e., education) or two (i.e., education and actual insulin injection demonstration) interventions. The reduction in $\mathrm{HbAlc}$ levels was the effect of either education or the actual insulin injection demonstration. A possible hypothesis was the Hawthorne effect among participants in 
the CG, who were aware of being studied and may have been possibly concerned about their behaviour changes [34]. Additionally, participants who refused insulin therapy may have high self-efficacy for diabetes self-management, including lifestyle modification and oral medication management. These participants may gain benefits from the educational programme without insulin therapy.

According to the results, the actual insulin injection administration can be introduced as a simulation of insulin therapy during a physician consultation. Patients can learn how to use the equipment and methods to administer insulin. This approach provides additional knowledge in addition to the general advice. Insulin preparation and injection techniques are the points that patients can learn from the demonstration. Moreover, patients can perceive and clarify the feelings and sensations related to insulin injections. This may help patients decide to accept or reject insulin therapy. Although the findings of this study cannot confirm the clinical benefits at 3 months, insulin acceptance is an important element for insulin initiation. This can provide further opportunities to adjust the dosage of insulin and withdraw some oral medications. The HbAlc levels were still high in both groups of study participants. Multiple solutions (e.g., prescribing simple regimen, using insulin pens instead of vial and syringe, ensuring self-monitoring) are recommended to overwhelm barriers to insulin acceptance and adherence [35]. A challenge of the actual insulin injection demonstration is the intervention is a time-consuming process that may disturb the routine clinical practice of physicians and healthcare providers.

There were two strengths of this study. First, this RCT was conducted in a real-world setting.
This reflected the possibility of implementing the actual insulin injection demonstration as a practical intervention. Second, all participants in both groups engaged in the follow-up assessment. There were some limitations of this study. A major limitation of the study was the blinding process. Both participants and physicians were not blinded due to the characteristics of the intervention. The authors did not assign any placebo to replace the actual insulin injection demonstration. This was a considerable issue of the pragmatic design [36, 37]. Second, the information on educational status of participants, which may affect the ability to learn insulin injections, was not collected. However, the authors excluded patients, who could not manage insulin therapy and had a history of poor medication compliance, to ensure the capability to administer insulin. Third, a small number of patients participated in this RCT. Therefore, the study may be considered as a pilot study for a larger trial. Lastly, the duration of the study was short. Although the primary outcome (insulin acceptance) of this study could be assessed during physician consultations, the insulin adherence rates between both groups were needed to carefully interpret.

\section{CONCLUSION}

This pragmatic RCT presented the positive effects of an actual insulin injection demonstration on insulin acceptance among participants with T2DM who previously refused insulin therapy. The physician-led demonstration encouraged a majority of participants who stated they had a fear of needles to initiate insulin therapy.

Introducere. Refuzul insulinoterapiei este o provocare atunci când se inițiază tratamentul cu insulină. Studiul își propune sa evalueze efectele pe care demonstrarea practică a injecțiilor cu insulină o are la acceptarea acestei terapii la pacienții cu diabet zaharat tip 2 (T2DM).

Metode. S-a realizat un studiu clinic randomizat (RCT). Participanții au fost pacienți cu T2DM cu vârste cuprinse între 18 și 65 de ani. Grupul martor (CG) a primit materiale educațional privind T2DM, pe când în grupul intervențional (IG), pe lângă materialele educaționale, pacienții au asistat și la o prezentare a injecției cu insulină, aceștia având o rată mai mare de acceptare a terapiei cu insulină. Au mai fost evaluate la 3 luni post-intervenție aderența la insulină, nivelurile hemoglobinei glicozilate (HbAlc) și rata efectelor adverse.

Rezultate. 49 de pacienți cu T2DM au fost împărțiți în cele două grupe - IG (24) și $C G$ (25). Rata acceptării insulinei a fost mai mare la grupul intervențional (RR 3,30, 95\% CI 1,59-6,82). La 3 luni de la intervenție aderența la insulină a fost mai mare la pacienții care au asistat la prezentare $(R R=3,75 \%, 95 \%$ CI 1,66-8,49). 
Nu s-au observat diferențe între efectele adverse, nivelurile HbAlc și modificările HbAl între cele două grupuri.

Concluzii. Demonstrarea injecțiilor cu insulină a dus la acceptarea acestei terapii la pacienții cu T2DM.

Correspondence to: Apichai Wattanapisit, School of Medicine, Walailak University, 222, Thaiburi, Thasala, Nakhon Si Thammarat, 80161 Thailand.

E-mail: apichai.wa@gmail.com, apichai.wa@wu.ac.th

Telephone: 6675672801

Fax: 6675672807

Acknowledgements: The authors wish to thank the nursing staff at Thasala Hospital for their support.

Conflict of interest disclosure: The authors declare that there are not conflicts of interest.

\section{REFERENCES}

1. NDISANG JF., VANNACCI A., RASTOGI S. Insulin resistance, type 1 and type 2 diabetes, and related complications 2017. J Diabetes Res. 2017; 2017:1478294.

2. TAYLOR R. Insulin resistance and type 2 diabetes. Diabetes. 2012; 61(4):778-9.

3. NICKERSON HD., DUTTA S. Diabetic complications: current challenges and opportunities. J Cardiovasc Transl Res. 2012; 5(4):375-9.

4. PAPATHEODOROU K., BANACH M., BEKIARI E., RIZZO M., EDMONDS M. Complications of diabetes 2017. J Diabetes Res. 2018; 2018:3086167.

5. SHAN PF., LI Q., KHAMAISI M., QIANG GF. Type 2 Diabetes mellitus and macrovascular complications. Int J Endocrinol. 2017; 2017:4301461.

6. JING X., CHEN J., DONG Y., HAN D., ZHAO H., WANG X., et al. Related factors of quality of life of type 2 diabetes patients: a systematic review and meta-analysis. Health Qual Life Outcomes. 2018; 16(1):189.

7. TRIKKALINOU A., PAPAZAFIROPOULOU AK., MELIDONIS A. Type 2 diabetes and quality of life. World J Diabetes. 2017; 8(4):120-9.

8. WOU C., UNWIN N., HUANG Y., ROGLIC G. Implications of the growing burden of diabetes for premature cardiovascular disease mortality and the attainment of the Sustainable Development Goal target 3.4. Cardiovasc Diagn Ther. 2019; 9(2):140-9.

9. GBD 2017 DISEASE AND INJURY INCIDENCE AND PREVALENCE COLLABORATORS. Global, regional, and national incidence, prevalence, and years lived with disability for 354 diseases and injuries for 195 countries and territories, 1990-2017: a systematic analysis for the Global Burden of Disease Study 2017. Lancet. 2018; 392(10159):1789-858.

10. INTERNATIONAL DIABETES FEDERATION. IDF Diabetes Atlas. 9 ed, 2019.

11. GBD 2017 CAUSES OF DEATH COLLABORATORS. Global, regional, and national age-sex-specific mortality for 282 causes of death in 195 countries and territories, 1980-2017: a systematic analysis for the Global Burden of Disease Study 2017. Lancet. 2018; 392(10159):1736-88.

12. KHAN MAB., HASHIM MJ., KING JK., GOVENDER RD., MUSTAFA H., Al KAABI J. Epidemiology of type 2 diabetes global burden of disease and forecasted trends. J Epidemiol Glob Health. 2020; 10(1):107-11.

13. SEURING T., ARCHANGELIDI O., SUHRCKE M. The economic costs of type 2 diabetes: a global systematic review. Pharmacoeconomics. 2015; 33(8):811-31.

14. MARIN-PENALVER JJ., MARTIN-TIMON I., SEVILLANO-COLLANTES C., DEL CANIZO-GOMEZ FJ. Update on the treatment of type 2 diabetes mellitus. World J Diabetes. 2016; 7(17):354-95.

15. INZUCCHI SE., BERGENSTAL RM., BUSE JB., DIAMANT M., FERRANNINI E., NAUCK M., et al. Management of hyperglycemia in type 2 diabetes, 2015: a patient-centered approach: update to a position statement of the American Diabetes Association and the European Association for the Study of Diabetes. Diabetes Care. 2015; 38(1):140-9.

16. CHAUDHURY A., DUVOOR C., REDDY DENDI VS., KRALETI S., CHADA A., RAVILLA R., et al. Clinical review of antidiabetic drugs: implications for type 2 diabetes mellitus management. Front Endocrinol (Lausanne). 2017; 8:6.

17. TRAN L., ZIELINSKI A., ROACH AH., JENDE JA., HOUSEHOLDER AM., COLE EE., et al. Pharmacologic treatment of type 2 diabetes: oral medications. Ann Pharmacother. 2015; 49(5):540-56.

18. LEE BW., KIM JH., KO SH., HUR KY., KIM NH., RHEE SY., et al. Insulin therapy for adult patients with type 2 diabetes mellitus: a position statement of the Korean Diabetes Association, 2017. Diabetes Metab J. 2017; 41(5):367-73.

19. LARKIN ME., CAPASSO VA., CHEN CL., MAHONEY EK., HAZARD B., CAGLIERO E., et al. Measuring psychological insulin resistance: barriers to insulin use. Diabetes Educ. 2008; 34(3):511-7.

20. POLONSKY WH., FISHER L., GUZMAN S., VILLA-CABALLERO L., EDELMAN SV. Psychological insulin resistance in patients with type 2 diabetes: the scope of the problem. Diabetes Care. 2005; 28(10):2543-5.

21. SONG Y., KU BJ., CHO J., JUN Y., KIM B., NAM S. The prevalence of insulin refusal and psychological insulin resistance among Korean patients with type 2 diabetes mellitus. Ann Transl Med. 2019; 7(23):760.

22. TAN WL., ASAHAR SF., HARUN NL. Insulin therapy refusal among type II diabetes mellitus patients in Kubang Pasu district, the state of Kedah, Malaysia. Singapore Med J. 2015; 56(4):224-7. 
23. WOUDENBERG YJ., LUCAS C., LATOUR C., SCHOLTE OP REIMER WJ. Acceptance of insulin therapy: a long shot? Psychological insulin resistance in primary care. Diabet Med. 2012; 29(6):796-802.

24. NG CJ., LAI PS., LEE YK., AZMI SA., TEO CH. Barriers and facilitators to starting insulin in patients with type 2 diabetes: a systematic review. Int J Clin Pract. 2015; 69(10):1050-70.

25. NGAMJARUS C., CHONGSUVIVATWONG V., McNEIL E. n4Studies: sample size calculation for an epidemiological study on a smart device. Siriraj Med J. 2016; 68:160-70.

26. ABU HASSAN H., TOHID H., MOHD AMIN R., LONG BIDIN MB., MUTHUPALANIAPPEN L., OMAR K. Factors influencing insulin acceptance among type 2 diabetes mellitus patients in a primary care clinic: a qualitative exploration. BMC Fam Pract. 2013; 14:164.

27. BANERJEE A., CHITNIS UB., JADHAV SL., BHAWALKER JS., CHAUDHURY S. Hypothesis testing, type I and type II errors. Ind Psychiatry J. 2009; 18(2):127-31.

28. BIN RSHEED A., CHENOWETH I. Barriers that practitioners face when initiating insulin therapy in general practice settings and how they can be overcome. World J Diabetes. 2017; 8(1):28-39.

29. KABADI UM. Starting insulin in type 2 diabetes: overcoming barriers to insulin therapy. Int J Diabetes Dev Ctries. 2008; 28(2):65-8.

30. RUSSELL-JONES D., POUWER F., KHUNTI K. Identification of barriers to insulin therapy and approaches to overcoming them. Diabetes Obes Metab. 2018; 20(3):488-96.

31. ALLEN NA., ZAGARINS SE., FEINBERG RG., WELCH G.. Treating psychological insulin resistance in type 2 diabetes. J Clin Transl Endocrinol. 2016; 7:1-6.

32. KAPOOR U., RAMASAMY G., SELVARAJ K., SAHOO JP., KAR SS. Does one-to-one demonstration with insulin pads by health-care providers improves the insulin administration techniques among diabetic patients of a tertiary care teaching hospital in South India? Indian J Endocrinol Metab. 2016; 20(6):767-71.

33. DAVIDSON MB. Insulin therapy: a personal approach. Clin Diabetes. 2015; 33(3):123-35.

34. McCAMBRIDGE J., WITTON J., ELBOURNE DR. Systematic review of the Hawthorne effect: new concepts are needed to study research participation effects. J Clin Epidemiol. 2014; 67(3):267-77.

35. RAKEL RE. Improving patient acceptance and adherence in diabetes management: a focus on insulin therapy. Adv Therapy. 2009; 26(9):838-46.

36. DAL-RE R., JANIAUD P., IOANNIDIS JPA. Real-world evidence: how pragmatic are randomized controlled trials labeled as pragmatic? BMC Med. 2018; 16(1):49.

37. ZWARENSTEIN M., TREWEEK S., GAGNIER JJ., ALTMAN DG., TUNIS S., HAYNES B, et al. Improving the reporting of pragmatic trials: an extension of the CONSORT statement. BMJ. 2008; 337:a2390.

Received $22^{\text {nd }}$ September 2020 